\title{
Research on the Application of Dewey's Teaching Thought on Economic Teaching
}

\author{
Li An \\ Yunnan Technology and Business University, Kunming, Yunnan, 650171
}

Keywords: Dewey’s Teaching, Economic Teaching, Application Study

\begin{abstract}
Since the 1980s, with the reform and opening-up of the ideological culture, the educational thoughts and educational practice of the Dewey School have gradually been objectively evaluated in China and have become a research hotspot. The content of the research has shifted from an overview introduction to the research in the depth field, and has drawn a number of basic and valuable research results. Because Dewey's educational thoughts better explain the cognitive laws and psychological states of the human learning process, many disciplines and fields have adopted and applied Dewey's educational thoughts.
\end{abstract}

\section{Introduction}

In his educational writings, Dewey repeatedly expressed his views on the nature of education: "Education is constantly growing." Dewey's educational thought was in the second half of the 19th century. After the "Civil War", the United States was undergoing large-scale expansion and In the period of transformation, traditional education and the rapid transformation of society seem to be out of place. In this context, Dewey applied pragmatic philosophy to the field of education. Combined with functional psychology and his own educational practice experience, he put forward his own views on the nature of education. That is, "education is life", "education is growth" and "school is society". Life is a process that has both an ideal side and a realistic side. Education is life, and education is to create conditions for education. Individuals fully enter life, internalize life as the diverse content provided by education, expand the interaction between people and the world of life, constantly surpass real life, and approach the possible real life. Promote life in the continuation of social life Update. Education is a means of promoting a better life, and it should also be a wonderful life. Education It is to prepare for the future life, but also for the present life. Therefore, the best education is to "learn from life" and "learn from experience". Growth is not only individual but also social. Dewey believes that education is continuous and education is life. Dewey emphasizes the important position of social factors in education. He believes that social environment has a very significant impact on education. In Dewey's educational ideology, The society is constantly evolving and changing. Education is of course not static, but a process of continuously transforming experience. The continuous renewal and development of the two aspects of society and education have prompted us to educate and have the right experience and Dewey people believe that education is a social life process, and school is one of the forms of social life. Schools should be a microcosm of society, a shrinking society. In schools, educators should work hard. Concentrate the real social life into a rudimentary state, so that the school can truly reflect the real life. Dewey pointed out that The basic meaning of school should have a real social life, the school itself should be the kind of social life. At the same time, to study and practice in close contact with the school campus life experience together, the freedom of mutual promotion between the two affect each other and common development.

\section{Dewey's Educational Thought in the Teaching of Western Economics}

The teaching objectives of Western economics can be divided into three levels: first, to cultivate students' interests and hobbies, to let students discover the charm of Western economics in the process of learning, to arouse curiosity and ignite the enthusiasm for learning; second, Improve 
students' basic abilities, let students learn the analysis and summary of general law problems in the process of learning, and through effective thinking training, they can also effectively improve their logical reasoning ability, language expression ability and insight into economic phenomena. Third, improve the ability to use from economic phenomena to economic theory to economic mathematical models. Students can skillfully use mathematical models to help explain economic phenomena. Therefore, the highest level of teaching aims to excavate from economic phenomena to essence, and then to generate rational expectations and accurate predictions of economic development. The teaching objectives of Western Economics cannot be achieved at one time and must be completed step by step.

First of all, Western economic theory itself has a wide range of fields, a wide range of content, and a large number of schools. It is composed of economic theories and academic views that are dominant in many economics schools. According to their different understanding of the role of market mechanisms, they can be divided into classical economics school and new and old Keynesian school. According to their understanding of the role of market mechanism, Can be divided into microeconomics and macroeconomics. Microeconomics is based on price theory, with individual consumers and individual producers as the research object, mainly composed of price theory, consumer behavior theory, producer theory, market theory, distribution theory, etc. Macroeconomics is based on Keynesian macro The economic theory is the core, and the whole national economy's activities as the whole research object. Its main theories include total demand and total supply theory, Keynes's effective demand theory, economic policy theory, inflation and unemployment theory, and economic growth theory. Many schools in Western economics have produced many economic works, representative figures and main points of view. Some economic theories complement each other and improve each other. Some economic theories exclude each other and oppose each other. Secondly, since the birth of Western economics, it has natural intrinsic connection with other disciplines such as mathematics, political science, ethics, psychology, etc., and from the development of economics in recent years, this connection has been enhanced. .

Western economics mainly includes microeconomics and macroeconomics. The microscopic part is centered on price theory, including equilibrium price theory, consumer behavior theory, producer behavior theory, distribution theory, general equilibrium theory and welfare economics, market failure and microeconomic policy, etc.; macroscopic part is Keynesian macroeconomic theory. At the core, including the theory of national income decision, the theory of unemployment and inflation, the theory of economic cycle and economic growth, the theory of economic development, macroeconomic policy, and so on. Because the content contained is of strong theoretical nature, it is easy to appear indoctrinated teaching methods in teaching. Moreover, in the face of so many theories, students may first be afraid of fear, so that teachers and students can not cooperate well, the teaching effect can be imagined. The theory of western economics has penetrated into various disciplines extensively, and there have been many marginal and interdisciplinary subjects, such as health economics, experimental economics, behavioral economics, tourism economics, economic sociology, and evolutionary economics. These disciplines are widely used in various fields. Their development has injected fresh blood into Western economics, and it has also influenced the research content and method innovation of Western economics.

\section{The Application of Dewey's Educational Thought in the Teaching of Western Economics}

In the first step, teachers should carefully create specific and vivid teaching scenarios, ask questions or let students discover problems and doubts on their own, in order to stimulate students' full enthusiasm for learning. The form of the scene can be varied and can be a piece of video material, or a text material or case. The design of the situation should pay attention to pertinence, effectiveness, inquiry and reality. You can find materials from real life to create scenarios, introduce hotspots or classic events in social and economic life (especially students), and contemporary college students' interest in economics mainly focuses on some hot economic issues that are closely related to their own interests. Such as: employment and unemployment rate, entrepreneurship, rising prices, income distribution, etc., so when explaining, you should choose some examples of 
life: if you are talking about price discrimination, you can use some amusement parks to collect foreign and domestic consumers. For different ticket prices, ask students to discuss why some parks and attractions will take price discrimination. In addition, teachers can also use the classroom to simulate experiments and create scenarios to engage students. For example, when explaining prices and employment, students can play the role of real wages and nominal wages by demonstrating the relationship between actual wages and nominal wages, demonstrating the relationship between output, employment, and prices. Let the students personally participate. Teachers can even encourage students to try to analyze problems or even design their own situations, do a good job of collecting and processing literature materials, and praise students' progress in a timely manner to further stimulate students' interest in learning, so that students are always in a proactive learning state. The sense of innovation and creativity can be further improved.

In this session, students can be organized for group discussions or class responses based on class schedules. Encourage students to express their ideas and let everyone discuss and think together. Through the way of communication and discussion, the students will have a clear and specific understanding of what they have learned, so that they can deepen the learning content, strengthen the learning focus, and inspire students to learn from each other and develop ideas. At this stage, there may be a lot of chaos in the classroom, and the role of the teacher at this time is quite important. While maintaining classroom order and urging students to learn and discuss, they should listen carefully to students' speeches, understand students' self-study, and give guidance to study, but do not give conclusions. In addition, students who are not good at speaking should be encouraged to participate in the speech. After the class discussion and answering the questions, the teacher should summarize the students' speeches, conduct rapid analysis and processing, and pave the way for the next step. In the process of analyzing problems, teachers should actively encourage students to speak. They should adopt a tolerant attitude toward the "weird questions" and "weird answers" put forward by students. Don't say yes, they should remind them to listen to others' opinions. . For example, when I talked about production theory and cost theory, I designed a situation: If you are ready to start a business after graduation, please list some business decisions that you think may be faced. There are four main reasons for student discussion: first, consider the cost of hiring employees, salary pricing, and the price of renting storefronts; second, consider the efficiency problem between input and output; third, consider market position and target group. The fourth question is the practical issue of considering the opinions of parents and the stability of work. The fourth question appears to be a "weird answer" that has nothing to do with the content of the class, but it is precisely the flash point of the student's answer, which has aroused everyone's resonance and improved the classroom activity and participation. Therefore, in response to such a situation, teachers must not deny the students' thinking, carefully protect students' self-confidence and self-esteem, give students a positive evaluation, and enhance students' interest in learning. Strive to further understand and master the content of learning through the discussion between teachers and students and between students and students. In the process, if the students have problems that have not been solved, then take these questions to the next stage to solve the problem.

\section{Conclusion}

Dewey's educational thought emphasizes students as the center, paying attention to students' active exploration and active discovery of knowledge. Students are the main body of the learning process. They do not passively accept knowledge. Instead, they actively form their own new knowledge and experience through continuous and active practice in the original knowledge system. Dewey's educational thought emphasizes the initiative, continuous reflection and truthfulness of learning. Through the use of Dewey's educational thoughts in the classroom teaching of Western economics, it cultivates students' sense of innovation and innovation, and enhances students' enthusiasm for learning and participation. Form the ability of students to think independently and solve problems. 


\section{References}

[1] Liu Fanqi. Analysis of the Current Situation of Economics Education in Colleges and Universities and Countermeasures [J].Economist, 2007(4)

[2] Liang Jingxi. Research on the Reform of Economics Teaching Methods [J]. China Higher Education Research, 2006 (6)

[3] Wang Yingzi. The Choice and Teaching of Cases in Economics Teaching [J]. Journal of Changshu Institute of Technology. 2007 (6)

[4] Zhang Yuanpeng. Research on Case Teaching Problems in the Teaching of Theoretical Economics in China [J]. Peking University Education Review. 2005 (Higher Education Management Special)

[5] Zhang Jie, Jiang Tao. Application of Discussion Teaching Method in Political Economics Teaching [J]. Journal of Hefei University, 2006(3) 